DOI: 10.20472/IAC.2019.050.007

\author{
KANRAWEE BUSAYANON \\ Faculty of Education, Ramkhamhaeng University, Thailand \\ KITTISAK LAKSANA \\ Faculty of Education, Ramkhamhaeng University, Thailand
}

ALONGKORN AUSAWASOWAN

Faculty of Education, Ramkhamhaeng University, Thailand

YASA MAHAMARN

Faculty of Education, Ramkhamhaeng University, Thailand

\title{
PROBLEM-BASED LEARNING: AN EFFICACIOUS WAY TO CREATE A BEAUTIFUL AND PLEASANT GLOBAL ENVIRONMENT
}

\begin{abstract}
:
This study aims to investigate the extent to which problem-based instruction can enhance pre-service Social Studies teachers' academic achievement and environmental problem-solving skills. A single group design experiment was conducted with 36 pre-service Social Studies teachers selected using the simple random sampling method. The research instruments employed in the study were: 1) five problem-based lesson plans, 2) a subjective test, and 3) a rubric to assess environmental problem-solving skills. Data obtained from a pre-test and a post-test were analyzed via a paired sample t-test. The findings reveal that after participating in the study, the pre-service Social Studies teachers' overall academic achievement and environmental problem-solving skills scores improved significantly, at a significance level of .05 with a large effect size of 2.843 and 6.500 respectively.
\end{abstract}

\section{Keywords:}

Academic achievement, environmental problem-solving skills, pre-service teacher, problem-based instruction

JEL Classification: 129 


\section{Introduction}

"Learning" is a process that influences and changes people's behaviors or opinions through hearing, touching, and using technology. Students receive or acquire knowledge through their teacher's presentations and the interactions between the instructor and the students or among students. The teacher plays a critical role in creating a supportive and friendly atmosphere that is conducive to learning through the use of various methods. For example, teachers should possess the quality of being assertive, active, cheerful, friendly, optimistic, positive, caring, compassionate, cooperative, empathic, gentle, and trusting. Additionally, they should also be capable of planning and be determined, goal-oriented, hardworking, well-organized,persistent, purposeful, and responsible with a strong will. More importantly, teachers must carefully select their teaching methods and develop positive interpersonal relationships with their students.

Over the years, various new learning theories have been developed, but constructivist learning theory is the focus of most educators. A concept within this theory is consistent with the teaching and learning paradigms of the $21^{\text {st }}$ century. It is believed that learning takes place when students create and manage their own knowledge base by connecting their newly acquired knowledge to prior knowledge. In $21^{\text {st }}$ century classrooms, instead of placing the teacher at the center of the students' learning and attempting to teach students a large amount of content in a short space of time, the learner should be the center of instruction, with the focus on learning through doing and active participation. Further, students should be provided with opportunities to formulate knowledge based on their own understanding and participation in active learning. Various learning styles have emerged from the constructivist learning concept, such as cooperative learning, the independent investigation method, and problem-based learning.

Problem-based learning (PBL) refers to learning that occurs with problems are used as the starting point to build bridges between old and new information, resulting in new knowledge (Barrows, 2000). PBL is a teaching method that employs problems to promote collaboration and self-regulated learning (Savery, 2006). Barrows (2000) described the important principles of PBL as: 1) a learner-centered approach; 2) small group work; 3) teachers as facilitators; 4) authentic problems to stimulate learning; 5) problem-solving skill development; and 6) self-directed learning. Meanwhile, HmeloSilver and Barrows (2006) also pointed out the optimal conditions to support PBL: 1) encouraging students to think and express their prior knowledge; 2) learning through applying knowledge in authentic contexts to help them accomplish their goals, with the teacher required to create authentic, real-world scenarios; and 3) encouraging students to obtain a more complete understanding of information by giving them the opportunity 
to elaborate knowledge in many ways, for instance by taking notes, through discussion or debate, asking questions, giving an oral report in groups, or by presenting to the class. Highly effective teaching and learning should emphasize activities that provide students with the opportunity to present their knowledge and abilities in various ways.

Schmidt (1993) described the three steps of PBL as follows:

Step 1:Students in small groups receive a real-life problem scenario that occurs in the past or present time. Each group of students helps the other members to analyze, identify, and classify the various issues found in the given scenario. Next, they must consider each issue and formulate questions about how it occurs and how it should be resolved. Meanwhile, they must also formulate hypotheses and then create learning objectives to prove the previously formulated hypotheses. However, the teacher should provide guidance in formulating the learning objectives in a way which is aligned with the course objectives.

Step 2: Students leave their group to search for useful information that corresponds to the learning objectives. After gaining sufficient information, they return to their group.

Step 3:All the groups of students have a discussion within their own group about the topics or issues they have researched. This allows the students to present the new extent to their understanding of the issues and how well they can find solutions to the problems. In addition, they are required to write a knowledge summary. At this stage, the teacher's role is to guide and facilitate in case the students have incomplete or inaccurate information, rather than to provide answers.

PBL has been used widely in various disciplines and can be employed in classrooms, communities, schools, and institutions (Borko, 2004). Desimone (2009) further mentioned that formal and informal activities can also develop teacher capabilities and their professional development. Therefore, professional development could also include reflection on lessons, co-teaching, reviewing instructional materials, class participation, and thorough self-monitoring of their own performance. Additionally, Desimone (2009) also pointed out that effective teacher professional development can enhance teachers' skills and change their attitudes and beliefs, resulting in significant teaching ability improvements and students' learning.

The primary objective of the present study was to investigate the extent to which problem-based instruction can enhance pre-service Social Studies teachers' academic achievement and environmental problem-solving skills. It was hypothesized that after problem-based instruction, the pre-service Social Studies teacherswould achieve higher mean scores for academic achievement and environmental problem-solving skills. This study makes a significant contribution to the fields of Education and Environment by 
serving as a guideline for designing courses or lessons to develop students' environmental problem-solving skills.

\section{Methodology}

An experimental research study was conducted with a sample of 36 pre-service Social Studies teachers enrolled in the "Population and Environment Education for Social Studies Teachers" course at the Department of Curriculum and Instruction, Faculty of Education, Ramkhamhaeng University. The study employedproblem-based instruction as an independent variable manipulated by the researcherto measure the effects on two dependent variables:academic achievementand environmental problem-solving skills.

During the development of the problem-based instruction, five lesson plans were carefully written and checked for content validity and objectivity by five experts with expertise in Social Studies and or course design. The experts were provided with an Item-Objective Congruence (IOC) Index form to verify whether the plans contained the necessary tasks and content to measure what they were intended to measure. Modifications or changes to the lessons were made based upon the experts' suggestions. Additionally, statistical tests including item difficulty index and discrimination indexwere performed to ascertain the reliability of afour-item subjective test.The resultsreveal distribution of item difficulty indices $(0.39-0.68)$ and discrimination indices $(0.45-0.78)$, indicating that the test is reliable.

To assess environmental problem-solving skills, the researcher created an analytic rubric consisting of four criteria (definingproblems, gathering information, formulating possible solutions to the problems, and developing action plans), and a fourpointscoring scale(1 Limited, 2 Developing, 3 Proficient, and 4 Exemplary).A narrative description was given under each criterion along with a scoring scale to indicate what the students were expected to perform for each score. The total score was worth 16 points,based on the aforementioned criteria and scoring scales.Next, the rubric was reviewed and checked for content validity and objectivity by the same five experts. The experts were requested to indicate the degree to which they thought that the four criteria on the rubric were congruent with the test items and narrative descriptionsof criteria along withthe performance levels of the problem-solving skills.All five experts entirely agreed that the problem-solving skill assessment rubric was valid with an IOC value of 1.0, which guaranteed that the rubric assessed what they were supposed to assess.With regards to reliability, two assessors were requested to assess the problemsolving skills using the same rubric, and a measure of internal consistency was applied using Cronbach's alpha.The results reveal anexcellent level of internal consistency, with the Cronbach's a coefficient values of .902 and .937. 
Numerical data were collectedfrom the pre-test conductedprior to the study,as well as from the post-test conducted after the study. Inferential statistics using SPSS's paired sample t-test was used to compare the pre-test and post-test data to measure the extent to which the pre-service Social Studies teachers' academic achievement and environmental problem-solving skills had improved after participating in the problembased instruction.

\section{Findings}

This section presents the findings on the extent to which the instruction was able to enhance the pre-service Social Studies teachers' academic achievement and environmental problem-solving skills.

\section{Pre-Service Social Studies Teachers' Academic Achievement}

Table 1 presents the pre-test and post-test data for academic achievement.

Table 1. Pre-test and post-test mean, standard deviation, and paired-sample T-Test for academic achievement

\begin{tabular}{|c|c|c|c|c|c|}
\hline Test & $\mathbf{M}$ & SD & $\mathbf{t}$ & $\mathbf{d f}$ & $\mathbf{p}$ \\
\cline { 1 - 3 } Pre-test & 20.81 & 3.10 & $23.562^{*}$ & 35 & .000 \\
\hline Post-test & 30.89 & 3.78 & & & \\
\hline
\end{tabular}

$\mathrm{n}=36, \mathrm{k}=45, \mathrm{r}=.738,{ }^{*} \mathrm{p} \leq .05$

The paired-sample t-test results show that the post-test results were higher than for the pre-test. The overall post test scores $(M=30.89, S D=3.78)$ were significantly higher than the pre-test scores $(M=20.81, S D=3.10), t(35)=23.562, p=.000)$, with a large effect size (Cohen's $d=2.843, r^{2}=.818$ ).

\section{Pre-Service Social Studies Teachers' Environmental Problem-Solving Skills}

Table 2 presents the pre-test and post-test data for environmental problem-solving skills.

Table 2. Pre-test and post-test means, standard deviations, and paired-sample T-Test on environmental problem-solving skills

\begin{tabular}{|c|c|c|c|c|c|c|}
\hline $\begin{array}{l}\text { Environmental Problem-Solving Skill } \\
\text { Criteria }\end{array}$ & Test & M & SD & $\mathbf{t}$ & df & $\mathbf{p}$ \\
\hline \multirow[t]{2}{*}{ 1) Defining problems } & Pre-test & 4.39 & 1.25 & \multirow[t]{2}{*}{$22.598^{*}$} & \multirow[t]{2}{*}{35} & \multirow[t]{2}{*}{.000} \\
\hline & Post-test & 9.25 & 1.63 & & & \\
\hline \multirow[t]{2}{*}{ 2) Gathering information } & Pre-test & 4.03 & 1.30 & \multirow[t]{2}{*}{$25.329 *$} & \multirow[t]{2}{*}{35} & \multirow[t]{2}{*}{.000} \\
\hline & Post-test & 9.11 & 1.06 & & & \\
\hline \multirow{2}{*}{$\begin{array}{l}\text { 3) Formulating possible solutions to the } \\
\text { problems }\end{array}$} & Pre-test & 4.17 & 1.25 & \multirow[t]{2}{*}{$29.955^{\star}$} & \multirow[t]{2}{*}{35} & \multirow[t]{2}{*}{.000} \\
\hline & Post-test & 9.22 & 1.02 & & & \\
\hline \multirow[t]{2}{*}{ 4) Developing action plans } & Pre-test & 4.75 & 1.23 & \multirow[t]{2}{*}{$42.603^{*}$} & \multirow[t]{2}{*}{35} & \multirow[t]{2}{*}{.000} \\
\hline & Post-test & 10.25 & 1.42 & & & \\
\hline
\end{tabular}




\begin{tabular}{|l|l|l|l|l|l|l|}
\hline \multirow{2}{*}{ Overall } & Pre-test & 4.33 & .76 & $63.098^{*}$ & 35 & .000 \\
\cline { 2 - 4 } & Post-test & 9.46 & .81 & & & \\
\hline
\end{tabular}

$\mathrm{n}=36, \mathrm{k}=20, \mathrm{r}_{1}=.626 ; \mathrm{r}_{2}=.495 ; \mathrm{r}_{3}=.620 ; \mathrm{r}_{4}=.839 ; \mathrm{r}_{\text {total }}=.809,{ }^{*} \mathrm{p} \leq .05$

The paired-sample t-test results show that the students' environmental problem-solving skills improved afterparticipating inthe problem-based instruction, evidenced by a higher score on the post-test $(M=9.46, S D=0.81)$ compared to the pre-test $(M=4.33, S D=$ $0.76),(t(35)=-63.098, p=.000)$, with a large effect size (Cohen's $\left.d=6.500, r^{2}=.956\right)$.

The pre-test and post-test results show that the students'environmental problem-solving skills significantly improved $(p=.000)$. The results reveal that the students performed better on the post-test in all four criteria:

1) The post-testscores for the'defining problems'criterion $(M=9.25, S D=1.63)$ were significantly higher than the pre-test scores $(M=4.39, S D=1.25), t(35)=-22.598, p=$ .000 .

2) The post-test scores for the 'gathering information'criterion $(M=9.11, S D=1.06)$ were significantly higher than the pre-test scores $(M=4.03, S D=1.30), t(35)=-$ $25.329, \mathrm{p}=.000$.

3) The post-test scores for the 'formulating possible solutions'criterion $(M=9.22, S D=$ 1.02) were significantly higher than the pre-test scores $(M=4.17, S D=1.25), t(35)=$ $-29.955, p=.000$.

4) The post-test scores for the 'devloping action plans' criterion $(M=10.25, S D=1.42)$ were significantly higher than the pre-test scores $(M=4.75, S D=1.23), t(35)=--$ 42.603, $\mathrm{p}=.000$.

\section{Discussion and Conclusion}

The findings of the present study reveal significant improvements inpre-service Social Studies teachers' academic achievement and environmental problem-solving skills after participating in the problem-based instruction. The findings are in line with many studiesas follows:

1.After participating in the problem-based instruction, the students had higher academic achievement, in line with Saitanoo (2011) who found that after participating in PBL webbased instruction students had greater learning achievement and creativity, with a statistical significance level of .01. Other studies also support the benefits of problembased instruction, for instance Na-Nongkhai and Keawkiriya's (2016) studyon cooperative problem-based instruction (CPBL) through Cloud Computing by Google 
Apps revealed that students participating in CPBL had above-average test scores compared to students taught with lectures and class exercises. Roungrong's (2018) study on the effectiveness of PBL instruction through tablet computers showed that the students' post-test scores were higher than their pre-test scores, with a statistical significance level of .05 , indicating that PBL instruction was able to motivate student learning since it focuses on what students want to learn. The lessons are created according to the problems that the students are interested in or encounter in everyday life. The problems can therefore be formulated based on their own experiences or from brainstorming in groups. More importantly, the teacher must adjust the instruction based upon the students' interests, as appropriate. Afterwards, the teacher and students cooperatively create learning activities related to that problem. The teacher can apply events from the news to encourage students to think of societal problems. This ensures that students are engaged in the learning process, promotes interaction among students, and encourages them to collaboratively find answers and solutions and gain new knowledge.

2. After participating in the problem-based instruction, the students' environmental problem-solving skills improved, in line with Lee and Blanchard's (2019) investigation on the use of PBL instruction at secondary level. They found that the PBL instruction was useful, meaningful, and worthwhile because the students worked together to accomplish their goals and practice their analytical thinking skills. In addition, Korpi, Peltokallio, and Piirainen (2018) conducted a three-and-a-half-year study with 15 undergraduate physical therapy students. The result showed the positive effects of PBL on the students' reflection on ideas, class participation, and acquisition of new knowledge. Step-by-step PBL instruction increased the students' critical thinking, logical thinking, and self-reflection skills. Argaw, Haile, Ayalew, and Kuma's (2017) study on PBL instruction in the field of physics found statistically significant differences in the learning achievement scores and problem-solving skills between the experimental group and the control group $(p<.05)$. In addition, the findings of this study are also in agreement with Dhabdhimsri and Naiyapatana(2017), who conducted PBL research that aimed at enhancing fourth-year nursing students' thinking process skills in adult nursing. The study revealed that the difference in the pre-test and post-test scores for both thinking process skills and attitudes was statistically significant $(p<.01)$.

It can be concluded that PBL instruction can enhance students' environmental problemsolving skills. The teacher plays an important role in organizing learning activities that foster students' reasoning and systematic problem-solving skills. In the PBL classroom 
students are encouraged to build their own practical solutions to deal with problems, apply their creative and critical thinking skills, search for and collect information, work collaboratively with others, keep records, and have discussions between each other.

\section{References}

Argaw, A. S., Haile, B. B., Ayalew, B. T., \& Kuma, S. G.(2017). The effect of problem-based learning (PBL) instruction on students' motivation and problem-solving skills of physics. EURASIA Journal of Mathematics Science and Technology Education, 13(3), 857-871.

Barrows, H. S. (1996). Problem-based learning in medicine and beyond: A brief overview. New Directions for Teaching and Learning, 1996(68), 3-12.

Barrows, H.S. (2000). Problem-based learning applied to medical education. Spring-field IL: Southern Illinois University Press.

Borko, H. (2004). Professional development and teacher learning: Mapping the terrain. Educational Researcher, 33, 3-15.

Desimone, L. M. (2009). Improving impact studies of teachers' professional development: Toward better conceptualizations and measures. Educational Researcher, 38, 181-200.

Dhabdhimsri, V., \& Naiyapatana,O. (2017). Enhancing thinking process skills in adult nursing using problem-based learning. The Journal of Boromarajonani College of Nursing, 33(1).

Hmelo-Silver, C. E., Duncan, R. G., \& Chinn, C. A. (2007). Scaffolding and achievement in problembased and inquiry learning: A response to Kirschner, Sweller, and Clark (2006). Educational psychologist, 42(2), 99-107.

Korpi, H., Peltokallio, L., \& Piirainen, A. (2018). Problem-based learning in professional studies from the physiotherapy students' perspective. Interdisciplinary Journal of Problem-Based Learning, 13(1), 4.

Lee, H.,\& Blanchard, M. R. (2019). Why teach with PBL? Motivational factors underlying middle and high school teachers' use of problem-based learning. The Interdisciplinary Journal of Problem-based Learning, 13(1).

Na-Nongkhai, L.,\& Keawkiriya, T. (2016). A development of the learning method of problem-based learning with cooperative learning on cloud computing by Google Apps. Rom Phruek Journal Krirk University, 34(3), 12-34.

Roungrong, P. (2019). A development of tablet-based learning model with problem-based learning. ThaiJO Journal of Education Naresuan University, 21(1), 156-171.

Saitanoo, P. (2011). Effects of creativity, responsibility and problem-solving skills of students learning by web-based PBL instruction and PBL diploma course on writing projection. Journal of Administration and Development, Mahasarakham University, 3(3).

Savery, J.R. (2006). Overview of problem-based learning: Definitions and distinctions. Interdisciplinary Journal of Problem-based Learning, 1(1), 9-20.

Schmidt, H. G. (1993). Foundations of problem-based learning - Some explanatory notes. Medical Education, 27, 422-432. 